УДК 231.01

DOI 10.35423/2078-8142.2020.1.05

\author{
Д. С. Морозова, \\ кандидат культурології, \\ докторант НПУ ім. М. П. Драгоманова \\ м. Київ, Украӥна \\ e-mail: morozovadaria@duh-i-litera.com \\ ORCID: https://orcid.org/0000-0001-5646-2851
}

\title{
БОРОТЬБА ВІЗАНТІЙСЬКИХ ШКІЛ В УКРАЇНСЬКІЙ МІСТИЧНІЙ АНТРОПОЛОГІЇ: ГРИГОРІЙ СКОВОРОДА І ПАЇСІЙ ВЕЛИЧКОВСЬКИЙ
}

У статті розглянуто вплив візантійської антропології на думку Григорія Сковороди і преп. Паїсія Величковського. За допомогою порівняльно-історичного методу та методу історії традиuiï (tradition history) простежено застосування украӥнськими богословами XVIII cm. візантійської патристичної спадщини. Доповнюючи нещодавнє дослідження М.Г.Бартоліні, присвячене розробиі Сковородою ідей Александрійської школи патристики, стаття аналізує мотиви, позичені ним у Антіохійської школи. Це, зокрема, своєрідна філософія дозвілля та християнський епікуреїзм, що відлунює вчення Йоана Золотоуста про легкість і природність християнського способу життя. Порівняння містичної антропологї двох богословів показало відмінність шляхів їхньої інтроспекції, яка у Сковороди присвячена, передусім, самопізнанню, а в Паїсія автентичному пошуку Іншого: Бога, наставника, подвижницької громади.

Ключові слова: Александрійська школа, Антіохійська школа, Григорій Сковорода, Паїсій Величковський.

Українські соціокультурні реалії середини XVIII ст., доби знищення Запорізької Січі, скасування Магдебурзького права і самоврядування, придушення низки народних повстань, розчарувала українську інтелектуальну еліту в теорії просвіченого абсолютиз-

(C) Морозова Д. С., 2020 
му, яку так натхненно прищепляли загалу попередні покоління могилянців. Кращі голови переходять від (марного за цих умов) соціального активізму до (ніколи не марного) самопізнання. «Знову, як і на порубіжжі XVI і XVII ст., коли йшлося про саме існування й виживання українського народу, стають актуальними концепції «внутрішньої людини», iї особистих зусиль, спрямованих на моральне і духовне піднесення» [6, с. 20]. Провідними постатями цієї зміни парадигм слушно називають таких несхожих могилянців, як Григорій Сковорода і Паїсій Величковський. Ці двоє натхненних мислителів і богословів (всупереч різноманітним міфам щодо них) якнайпотужніше відроджували зв'язок київської традиції з іії візантійським корінням. Але, як буде показано в цій статті, Сковорода i Величковський апелювали до різних, навіть протилежних, течій візантійської антропології - Александрійської та Антіохійської шкіл.

Дослідники Григорія Савича Сковороди і Паїсія Величковського інколи зауважують загадковий паралелізм їхніх доль [7]. Обидва мислителі походили з козацтва, народилися на Полтавщині в 1722 р., а померли в листопаді 1794 р., обидва в 1730-ті роки навчалися в Могилянських школах, але відмовились від пропонованої їм кар'єри, обидва провели переважну частину життя в мандрах Україною і закордоном, хоча обидва наголошували на перевазі інтроспекції над пізнанням світу... За цими та іншими фактичними «римами» стоять суттєві духовні й інтелектуальні паралелі між двома провідними богословами українського бароко - та не менш промовисті розбіжності. Однак, всупереч поширеним стереотипам, ці розбіжності не варто вимірювати «світськістю» Сковороди і «церковністю» Паїсія, - вони зумовлені, насамперед, залежністю обох християнських, і навіть православних мислителів від різних патристичних традицій.

Нескінченні зовнішні мандри (странствія) обох подвижників тим чи іншим чином відбивають внутрішню подорож кожного 3 них. Однак ці внутрішні мандри двох діячів відрізняються не менш, ніж карти їхніх географічних странствій. В очах Сковороди, головна подорож філософа - це платонічний рух пізнання самого себе. Марія Грація Бартоліні вбачає в його творчості втілення пізньоантичної тенденції, яку Етьєн Жільсон назвав «християнсь58

H.Skovoroda Institute of Philosophy of the NAS of Ukraine 
ким сократизмом», - безумовний пріоритет cognitio sui над пізнанням світу [1, с. 77]. У цьому сенсі навіть наймогутніші біблійні наративи міграції - як-от покликання Авраама і Вихід євреїв з Сгипту - означають «фактично вихід з простору тілесної зовнішності (Сгипет) у напрямі до внутрішнього простору самопізнання». Тут Сковорода йде слідом за такими яскравими платонічними екзегетами, як Філон і Григорій Ниський. Дослідниця простежує в Григорія Савича послідовне протиставлення цеентротяжних і центробіжних дієслів (наприклад, входит - обходит): перші описують поведінку праведників і мудреців, другі - грішників і безумців. Як не парадоксально, вічний подорожанин Сковорода постійно вживає образ вулиці, околиці та кружного руху як метафори блуду й омани, а образ домівки - як метафору філософського самозаглиблення і самовдосконалення. Саме 3 цієї причини позитивним геро$€$ у нього постає міфологічний Нарцис (Наркісс), який «амурится дома», тобто кохає самого себе, займається нескінченним самопізнанням, не відволікаючись ні на що зовні. Натомість Давидова жінка Мелхола заслуговує догану не тому, що засудила чоловіка за його святий танок перед Богом, - а лише тому, що побачила його, виглядаючи з вікна назовні, на вулицю: «Мир есть Улица Мелхолина, Блудница Вавилонска» [10, I, с. 157; 1, с. 77].

Отже, подорожування Григорія Савича $є$ не так мандрами по світу, як мандрами від світу, що ловить і не може впіймати, - мандрами до самого себе. Відмова Сковороди від чернецтва і церковної кар'єри є рухом емансипації від контролю з боку інших та втечі від усякої лояльності хоч би яким інституціям. Його Мудрість не обмежується жодною конфесією і жодною релігією. У «Розмові про премудрість» вона зізнається філософові, що в неї багато імен: греки звуть їі Софією, римляни - Мінервою, християни - Христом; $\epsilon$ в неї особливе ім'я і «в хінських сторонах» (у Китаї) [11, с. 192]. Це легке ставлення Сковороди до релігійної істини якнайкраще унаочнює неоплатонічні витоки популярної сьогодні позиції віруючого поза Церквою («у мене Бог в душі»). Не дарма він гаряче підписувався під «антиклерикальними» і водночас «ісихастськими» словами язичника Сенеки, що закликав триматися подалі від усяких «храмових сторожів»: «Бог - побіч тебе, з тобою, в тобі! Так-так, Люцилію: десь у глибині нашого єства поселився священ- 
ний дух - спостерігач наших добрих і лихих учинків, наш сторож. Як ми ставимося до нього, так він - до нас» (Сенека, моральні листи до Люцилія, XLI, пер. А. Содомори).

Духовна емансипація Сковороди, якому ці слова видавалися «громом $з$ третього неба», якнайкраще виражає властиве добі Просвітництва уявлення про універсальність і всюдисущність істини. Однак це дистанціювання від «церковних огорож» є зовсім не нігілізмом атеїста - а, навпаки, самозосередженням християнського неоплатоніка і по-своєму вірного послідовника александрійського православ'я [Пор.: 4].

Для преп. Паїсія Величковського рух інтроспекції має аж ніяк не менше значення, ніж для Сковороди. Власне, цей рух занурення ума (võ̃ $)$ у серце становить суть філокалічного відродження справи життя молдавського Старця. Утім, підхід двох мислителів до цієї практики значно відрізняється. Якщо для Сковороди само-зосередження є суто мисленнєвим рухом, то для Паїсія це фізично-інтелектуальне молитовне дійство, пошук у глибинах себе точки, з якої можливо розпочинати автентичну розмову з Іншим. Пошук Бога наявний і в духовних мандрах Сковороди, але ці пошуки мають помітно інший характер. Шлях думки від чуттєвого до умоглядного, від складного до простого, від численного до Сдиного у Сковороди є невіддільним від шляху самопізнання, вивчення законів та здатностей власного мислення. Натомість Паїсій якщо й цікавиться закономірностями власної свідомості, то, насамперед, для того, щоб день по дню і ніч по ночі ретельно очищати ії для зустрічі з особистісним Богом, Ісусом Христом.

Самозаглиблення та іронічний погляд на дійсність, втеча від світу та алегоричне подвоєння його, увага до ментального життя i його законів - це все вияви зв'язку Сковороди з Александрійською школою. Однак, у переважно александрійському, платонічному контексті думки філософа все ж неявні певні суто антіохійські мотиви. Врешті решт, як Паїсій перекладав та студіював александрійських авторів, так і Сковорода вивчав і цитував антіохійців.

Можливо, найбільша співзвучність між Золотоустом і Сковородою стосується їх поглядів на дихотомію свят і буднів, або otium i negotium, як Григорій Савич називав це слідом за італійськими гуманістами. Вільний час, для Сковороди, - альфа і омега 60

H.Skovoroda Institute of Philosophy of the NAS of Ukraine 
справжньої філософії. У нього простежують ціле вчення про перевагу над буднями свят, що їх він розумів як час, звільнений від житейської метушні для наук і споглядання. Упразднитеся $i$ paзумъйте (Пс. 45:11) - ці біблійні слова, в яких ввижається гнівна загроза, Сковорода сприймав зовсім інакше. Дієслово «упразняти», етимологічно пов'язане зі звільненням і святом (рос. - праздником), він асоціює із «Глумом» - забавою, розрадою. Дозвілля є ідеальним часом для «розуміння» - пізнання Бога. Відтак, Григорій Савич - чи не перший український «дауншифтер» - закликає перетворювати все своє життя на otium, сповнений споглядання.

У своїх міркуваннях про незамінний otium Сковорода 3 повним правом покликається на Золотоуста, не вдоволеного різким розділенням життя християн на будні та свята. Як переконаний свт. Йоан, не варто абсолютизувати календарні свята, на кшталт Пасхи чи П'ятдесятниці (напр.: De sancta Pentecoste, 1; PG 50.455). Кожна неділя є Пасхою, і взагалі «Празднику не Время Творец, но Ведренная Совесть», як цитував свт. Йоана Сковорода [14]. Відтак, християнам личить проживати кожний день як свято богоспілкування. Ця ідея щоденного святкування справді об'єднує двох богословів різних епох. Утім, Григорій Савич навіть Золотоуста читає крізь свої улюблені неоплатонічні окуляри, наприклад, переказуючи його таким чином: «Вот мысль Іоанна Златоустаго. Праздник-де - не время творить, но чистый помысл. Сердце есть море неограниченное, а помыслы суть волны. Естли помыслы тихи, тогда спокойное сердце» [10, II, с. 215; 1, с. 124]. Як бачимо, український Сократ додає Золотоустовій еортології інтелектуалізму александрійської традиції.

Із «теологізацією отіуму» пов'язана ще одна точка конгеніальності Сковороди з Антіохійською школою, а саме - епікуреїзм. Попри весь подвижницький антураж Сковороди як «самотнього мандрівника-аскета, котрий цурається світу, з усіма його принадами ... «голяка-страннника», Григорій Савич дистанціювався від крайнощів умертвіння плоті так само, як і від зайвих розкошів, «намагаючись іти шляхом «золотої мірноти» [11, с. 195]. Філософ, що називав Христа «еврейськім Епикуром» [10, I, с. 89] і захищав «сладость сокровенную в Епикурском словњ» від античних крити- 
ків, значною мірою спирався в цьому на інтуїції антіохійських богословів.

Безпосередній вплив епікурейства на Золотоуста і Феодорита Кирського простежують, зокрема, в їх уявленні про Церкву як «гавань» $(\lambda \mu \mu \dot{v}$ о $)$, в якій душа, засмучена внутрішніми бурями, може

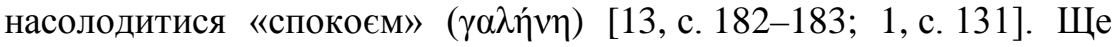
більш явно відсилає до Антіохії відоме епікурейське переконання Сковороди, що все поправді насущне досягається легко і природно. «Благодарение всеблаженному Богу, что нужное сделал нетрудным, а трудное ненужным!» Цей вислів, записаний найближчим учнем Григорія Савича М. Ковалинським [3], підсумовує один 3 діалогів мислителя, де Сатана називає шлях християнського життя «претрудным», за що Михаїл скидає його з небес («Горе тебъ! нарицающему... сладкое горким, легкое же бременем») [15]. Цей ар-

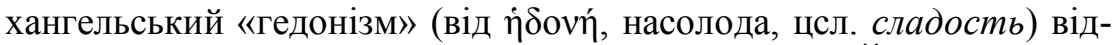
силає не лише до творів Епікура, а й до проповідей Йоана Золотоуста. Антіохійський аскет раз у раз нагадував своїм слухачам, якими вимогливими й трудомісткими $є$ афери, в які втягує їх диявол, - i яким легким і приємним є тягар Христових заповідей (напр.: Ad populum ant. 19.4). Тож епікурейство Сковороди лише почасти пов'язане з його класичними студіями (започаткованими Симоном Тодорським); значною мірою воно є вкоріненим у зважене і природне християнство Антіохійської школи.

Цікаво, що одна 3 найпомітніших розбіжностей між Сковородою і Величковським пролягає в освітній царині та в каналах впливу їхньої спадщини. Розбіжності в їхньому ставленні до освіти та просвіти певним чином відтворюють структурну відмінність між Александрійською академією та Антіохійською школою, 3 яких перша була розвиненою інституціоналізованою школою, а друга - радше неформальним монастирським освітнім осередком.

Сковорода, з одного боку, освітянин до мозку кісток: він уважно навчається, бере участь у видавничих проектах своєї alma mater, займається репетиторством, викладає у провідних академіях. Його negotioum цілком вписується в університетський формат, актуальний ще від часів Александрійської академії. 3 іншого боку, через свій аскетичний, усамітнений і філософський спосіб життя, «невловний птах» виглядав диваком як у чернечому, так і в універ62

H.Skovoroda Institute of Philosophy of the NAS of Ukraine 
ситетському середовищі, яке він неодноразово залишав через власні духовні принципи [11, с. 209-210]. Із його байдужістю до світських маркерів успіху, Григорій Савич дещо скидається на свого александрійського колегу преп. Арсенія, блискуча педагогічна кар'єра якого закінчилася «втечею від людей» у пустелю.

Григорій Савич не цурався товариства і вчителювання, «обирав і любив друзів за їхнім серцем», та й учнів закликав знати міру в униканні юрби [3]. Однак він все ж був справжнім поетом самоти. Сковорода відзначав щодо неї: «Це щось велике й властиве лиш найвеличнішим мужам і мудрецям... святі люди й пророки не лише зносили нудьгу повної самотності, а й безумовно втішалися самотою». Словами його учня, він відчував «смак у свободі від марноти й житейських пристрастей, в убогому, але безтурботному стані, в самотині, але без розладу із самим собою» [3]. Це позначилося і на його спадку, який з покоління в покоління звертається не так до спільнот, як до «приватних мислителів», внутрішньо незалежних вільнодумців, випестуваних світською університетською освітою.

Подібно до свого земляка, преп. Паїсій Величковський теж не вписався в освітню парадигму свого часу. Не закінчивши навчання, відкинувши перспективу церковної кар'єри, у 1739 р. він скандально залишив Могилянку (як згодом Сковорода залишить Харківський колегіум) і вирушив у багаторічні мандри Україною, Придунайськими князівствами й Грецією. Однак ця втеча, якщо придивитись до неї уважно, не була втечею від світу, в тому сенсі, як втеча Сковороди. Подорожі Величковського завжди були мандрами в пошуках Іншого. Наскрізним мотивом Автобіографiї Паїсія $\epsilon$ палке прагнення долучитися до духовно близької чернечої громади, знайти справжнього духовного отця, а згодом також пошуки книг давніх духовних наставників. У всіх цих пошуках Інший постає не завадою, а незамінним помічником у пошуках себе і свого Бога.

Преп. Паїсій, який усе життя шукав наставника і так його i не знайшов, врешті решт сам виявився наставником для тисячі монахів Нямецької лаври і безлічі мирян. Його величезна громада 3 десяти національностей, які молилися щонайменше трьома мовами, була настільки гетерогенною, що по смерті Старця нікому так i 
не вдалось утримати її від внутрішніх чвар. Але навіть після того, як члени цієї громади розійшлися по всьому православному світу, вони створили десятки нових громад, що наслідували Нямецьку обитель - зокрема, в іiі наслідуванні давніх патристичних взірців. Ця воля до творення кіновії («спільножительства»), служіння ближнім та формування церковних просвітніх установ безпосередньо стосується захоплення Паїсія антіохійською антропологією і соціальною думкою.

Відповідно, ідеї, твори, переклади та, ймовірно, навіть літургійні звичаї старця Паїсія поширювалися, передусім, цими каналами учнівства - від монастиря до монастиря [5]. Така модель освіти цілком відтворює витоки Антіохійської школи, що, попри свій тісний зв'язок зі світською риторською школою Антіохії, не мала інституційної форми і втілювалася переважно у катехизації та чернечому наставництві.

Отже, попри паралелізм, який простежують у долях Григорія Сковороди і Паїсія Величковського, їхня думка має істотно різні вектори. Хоча ровесники, земляки і співучні Сковорода і Величковський обидва прагнули перетворити своє життя на шлях до себе, значною мірою ці шляхи лучили в різних себе. Те спільне, що ми бачимо в їх життях, так чи інакше дотичне і до православного християнства, і до класичної освіти. Але значні відмінності між ними - які даремно пояснювати через дихотомію секулярного i клерикального - значною мірою втілюють контрапункт антропологічних ідеалів Александрійської і Антіохійської шкіл. Яскравий неоплатонік Сковорода лише подекуди виявляє близькість до антіохійської філософії. Це виявляється, зокрема, у його поглядах на працю й дозвілля (otium i negotium), у посиланнях на християнський епікуреїзм Йоана Золотоуста тощо. Однак загалом думку Сковороди більш доречно розглядати в контексті платонічної теології Александрійської школи (що засвідчують дослідження М. Г. Бартоліні). Натомість, богословські уподобання Паїсія значною мірою визначаються впливом антіохійської школи патристики з їі антропоцентризмом, соціоцентризмом і великою схильністю до творення киновії, з іiі потужним акцентом на спілкуванні та співпричасті. 


\section{ЛІТЕРАТУРА ТА ПРИМІТКИ}

1. Бартоліні М. Г. Пізнай самого себе. Неоплатонічні джерела в творчості Г. С. Сковороди. К. : Академперіодика, 2017. 160 с.

2. Брискина-Мюллер А. «Прилепися всею душою твоею чтению книжному!» Чтение - забытая категория аскетического богословия прп. Исаака Сирина, Григория Синаита и Паисия Величковского. Богословский вестник. 2018. № 31. С. 93-122.

3. Ковалинский М. И. Жизнь Григория Сковороды, написання в 1794 г. в прежнем вкусе. Киевская старина. 1886. T. XVI. С. 103-150.

4. Малахов В. А. Христологічні мотиви у творчості Г. Сковороди. Право бути собою. К. : Дух і літера, 2008. С. 167-180.

5. Морозова Д. С. Преп. Паїсий Величковський на перехресті богослужбових традицій XVIII ст. Афонское наследие. 2017. № 5-6. С. 286300.

6. Нічик В. М., Хижняк 3. І. Києво-Могилянська академія та українсько-німецькі культурні зв'язки. Наукові записки КМА. Історичні науки, 2000. T. 18. С. $12-24$.

7. Окара А. Паїсій Величковський та Григорій Сковорода у контексті духовної культури XVIII ст. Філософія. Історія культури. Освіта: Доповіді та повідомлення III Міжнародного конгресу україністів. Харків : Око, 1996. С. 70-76.

8. Паисий Величковский, преп. Автобиография. Житие. М. : Св.Троицкая Сергиева Лавра, 2006. 203 с.

9. Сковорода Г. Повна академічна збірка творів. Харків : Майдан, 2011. 1398 с.

10. Сковорода Г. Повне зібрання творів: У 2-х т. К. : Наукова думка, 1973.

11. Ушкалов Л. Ловитва невловного птаха: Життя Григорія Сковороди. К. : Дух і літера, 2017. 368 с.

12. Чорноморець Ю. П. Християнський платонізм Григорія Сковороди. Філософська думка. 2014. № 5. С. 88-97.

13. Schmid M. Epicuro et l'epicureismo cristiano. Brescia, 1984. 226 p.

14. Сковорода цитує тут автентичний вислів свт. Йоана з Contra eos qui subintroductas habent virgins, 12.7. У листі до М. Ковалинського від 13 листопада 1762 p. він наводить ці слова в оригіналі й витлумачує їх латиною [1, с. 124].

15. «Борьба и Пря о Том: Претрудно быть злым. Легко быть благим» [9, c. 830-832]. 


\section{REFERENCES}

Bartolini, M. G. (2017). Know Yourself. Neoplatonic sources in the work of G. S. Skovoroda. Kyiv: Akademperiodika. 160 p. [In Ukrainian].

Briskina-Müller, A. (2018). Reading as a forgotten category of ascetic theology of St. Isaac the Syrian, St. Gregory of Sinai and St. Paisius Velichkovsky. Bogoslovskij vestnik (Theological Bulletin), 31, 93-122. [In Russian].

Kovalinsky, M. I. (1886). The Life of Gregory Skovoroda, written in an ancient style in 1794. Kievskaya starina (Kiev old), XVI. [In Russian].

Malakhov, V. A. (2008). Christological motives in G. Skovoroda's work. Kyiv: Spirit and Letter. [In Ukrainian].

Morozova, D. S. (2017). St. Paisius Velichkovsky at the crossroads of liturgical traditions of the18th century. Afonskoje nasledije (Mount Athos heritage), 5-6, 286-300. [In Ukrainian].

Nichyk, V. M. \& Khyzhnyak, Z. (2000). Kyiv-Mohyla Academy and Ukrainian-German Cultural Relations. Naukovi zapysky KMA. Istorychni nauky (Scientific notes of the Kyiv-Mohyla Academy. Historical sciences), 18, 12-24. [In Ukrainian].

Okara, A. (1996). Paisius Velichkovsky and Gregory Skovoroda in the Context of 18th-Century Spirituality. Filosofiya. Istoriya kultury. Osvita (Reports and communications of the 3rd International Congress of Ukrainianists) (Philosophy. The history of culture. Education: Reports and Announcements of the Third International Congress of Ukrainianists). Kharkiv: Oko, 70-76. [In Ukrainian].

Paisius Velichkovsky. (2006). Autobiography. Life. Moscow. 203 p. [In Russian].

Skovoroda, G. (2011). Complete Works. Kharkiv: Maidan. 1398 p. [In Ukrainian].

Skovoroda, G. (1973). Complete Works in 2 Vols. Kyiv: Naukova dumka. [In Ukrainian].

Ushkalov, L. (2017). Hunting the Uncatchable Bird: The Life of Gregory Skovoroda. Kyiv: Spirit and letter. 368 p. [In Russian].

Chernomorets, Yu. P. Christian Platonism by Gregory Skovoroda. Philosophical Thought (Philosophical thought), 5, 88-97. [In Ukrainian].

66

H.Skovoroda Institute of Philosophy of the NAS of Ukraine 
Schmid, M., 1984. Epicuro et l'epicureismo cristiano. Brescia, 226 p. [In Russian].

\title{
Daria Morozova
}

Candidate of Culture (Ph.D.), doctoral student of National Pedagogical Dragomanov University; Kyiv, Ukraine; e-mail: morozovadaria@duh-ilitera.com; ORCID: https://orcid.org/0000-0001-5646-2851

\section{The Fight of Byzantian Schools in Ukrainian Mystical Anthropology: Gregory Skovoroda fnd Paisius Velichkovsky}

\begin{abstract}
The aim of the paper is to compare the influence of Byzantine anthropology on the thought of Gregory Skovoroda and St. Paisius Velichkovsky. The comparative-historical method and the Tradition history method are applied for the analysis of the role of Byzantine patristic heritage in the work of the two 18thcentury Ukrainian theologians. In addition to M. G. Bartolini's recent study of Skovoroda's use of the ideas of the Alexandrian School, the paper traces the motives that he borrowed from the School of Antioch - above all, a specific leisure philosophy and Christian Epicureanism that echoes John Chrysostom's doctrine of the ease and naturalness of the Christian way of life. Comparing the mystical anthropology of the two theologians showed the difference in the ways of their introspection. In Skovoroda it is devoted, first and foremost, to self-knowledge, while in Paisius - to the authentic search for the Other: God, teacher, ascetic community. For all the parallelism that they trace in the fates of Gregory Skovoroda and Paisii Velichkovsky, their opinion has substantially different vectors. Although peers, countrymen, and singers Skovoroda and Velichkovsky both sought to turn their lives on the path to themselves, to a large extent these paths were different in themselves. The commonality we see in their lives is one way or another related to Orthodox Christianity and classical education. But the clear differences between them - which are in vain to be explained by the dichotomy of the secular and clerical - largely embody the counterpoint of the anthropological ideals of the Alexandrian and Antiochian schools. The bright Neo-Platonist Frying pan only proves to be close to Antioch philosophy. This is reflected, in particular, in his views on work and leisure (otium and negotium), in references to the Christian epicureanism of John Chrysostom and the like. However, in general, Skovoroda's opinion is more
\end{abstract}


appropriate to consider in the context of the Platonic theology of the Alexandrian School (as evidenced by M. Bartolini's research). Paisius's theological preferences, on the other hand, are largely determined by the influence of the Antioch school of patristics, with its anthropocentrism, sociocentrism, and its great propensity for cinematic writing, with its strong emphasis on communication and fellowship.

Keywords: Alexandrian School, School of Antioch, Gregory Skovoroda, Paisius Velichkovsky. 